\title{
Nickel -Titanium rotary instruments in
}

\section{retreatment cases}

\author{
Emilia Karova ${ }^{1}$, Violeta Dogandzhiyska ${ }^{1}$, Irina Tsenova-Ilieva ${ }^{1}$, \\ Miriana Raykovska ${ }^{2}$, Sherihan Zongova-Adem ${ }^{3}$
}

1. Department of Conservative Dentistry, Faculty of Dental Medicine, Medical University, Sofia, Bulgaria;

2. Dentist, Dental Studio 32, Private Dental Practice, Sofia, Bulgaria;

3. Center of Integrated Dental Medicine, Faculty of Dental Medicine, Medical University, Sofia, Bulgaria.

\begin{abstract}
Introduction: Complete root canal filling material removal is essential for the good outcome of the secondary endodontic treatment. Different methods and hand and rotary instruments have been proposed for better filling removal. Aim: The aim of this article is to review the most commonly used approaches for removal of canal filling materials, analysing the scientific data from the last 10 years mainly. Materials and Methods: Articles related to the problem were reviewed with the aim to summarize the techniques mostly used in retreatment protocols and the effectiveness of the NiTi instruments for removing the root canal filling materials. Conclusion: None of the techniques described in the up-to-date scientific literature is considered $100 \%$ effective in removing of root filling materials. Supplementary approaches have to be introduced for more efficient cleaning of the root canal walls, ensuring better prognosis of the endodontic retreatment cases in the daily dental practice.
\end{abstract}

Keywords: Endodontic retreatment, NiTi retreatment systems, NiTi rotary instruments.

\section{Introduction}

Endodontic treatment is a procedure performed in the presence of pulpal disease and includes proper mechanical preparation, disinfection and obturation of the root canal system. When performed properly, the success rate of the endodontic treatment is over $90 \%$ (1). Although it is considered a safe and predictable procedure (2), in some cases periapical inflammation can occur. 
The available treatment options after a failed primary endodontic therapy are nonsurgical orthograde endodontic retreatment (NOER), surgical endodontic treatment or extraction. The first choice procedure is the NOER for which a tooth survival rate of $95,3 \%$ is reported (1). The main goal of the orthograde endodontic retreatment is to completely remove the root filling material, possibly contaminated with microorganisms and their toxins, and to regain access and patency to the apical foramen, enabling the proper debridement of the root canal space and reestablishing healthy periapical tissues $(3,4)$.

The most commonly used material for root canal obturation is the gutta-percha in combination with different types of sealers. Several retreatment techniques for the removal of the root canal filling material are described, including hand files, different engine-driven NiTi instruments, specially designed for shaping of the root canals or their retreatment, sonic and ultrasonic devices, instruments producing heat, solvents, lasers and combinations between them $(5,6,7)$.

Although the contemporary retreatment techniques are sufficiently effective, none of them results in root canal walls absolutely clean of remnants. This makes some authors consider the use of supplementary retreatment techniques.

\section{Review Results}

The use of NiTi alloy in endodontics was firstly presented in 1988. It consists of three microstructural phases - austenite, martensite and an intermediate R-phase. When in austenitic phase the alloy is hard, strong and owns superior superelastic properties. In its martensitic phase the alloy is soft and easily deformed, owns a specific "shape memory effect", and has superior cyclic fatigue resistance. The alloy in the martensite phase changes into the austenite one when heated. Upon cooling the changes go in the opposite direction. The alloy suffers the same transformations under external stress and is known as induced martensitic transformation. It is of great importance for one of the special mechanical properties of the NiTi alloy - its superelasticity and greater flexibility, resulting in fewer procedural errors, especially in curved root canals.

Several additional procedures for increasing the NiTi flexibility and fracture resistance, like electropolishing and thermomechanical treatment of the alloy, are used by the manufacturers $(8,9)$.

The presence of $\mathrm{NiTi}$ instruments in the field of endodontic treatment shortens the operating time, decreases the operator and patient's fatigue and generally facilitates the procedure.

$\mathrm{NiTi}$ systems consisting of files with different geometry and number, made of various types of NiTi wire and driven with continuous or reciprocating rotation were investigated in the last 10 years (10-17).

Although engine-driven instruments are reported to be unable to completely clean the root canal space from filling remnants, they are still preferred to manual instrumentation for removal of the bulk of canal obturation, as they require less operating time and in most of the cases are superior or equal to hand stainless-steel instruments (18-22).

$\mathrm{NiTi}$ instruments specifically designed for retreatment were manufactured and introduced to the market Mtwo Retreatment (VDW, Munich, Germany), D-Race (FKG, La Chaux de Fonds, Switzerland), Protaper Universal Retreatment (Dentsply, Ballaigues, Switzerland), R Endo (Micro-Mega, Besancon, France), etc. Mtwo Retreatment set consists of two instruments - R1 (\# 25.05) and R2 (\# 15.05) which have an Sshaped cross-section, two cutting edges and active tips. The R1 file is used to remove the filling material from the coronal two thirds of the root canal while the R2 file is used for the apical area and reaches the working length. The instruments are used at a speed of $300 \mathrm{rpm}$ and a torque of $1.2 \mathrm{Ncm}$, according to the manufacturer's instructions $(23,24)$. 
Two files are included in the D-Race retreatment system - DR1 (\# 30.10), and DR2 (\#25.04). The first is used for shaping the coronal part of the root canal and has an active tip for better penetration into the filling material, while the second one is used to clean the remaining root canal $(20,25)$.

Pro Taper Universal Retreatment (PTUR) system consists of three files - D1, D2, D3, used for removing the filling material from the coronal, middle and apical third of the root canal, respectively. They have a convex triangular cross section, various tip sizes and tapers -30.09 for D1, 25.08 for D2 and 20.07 for D3. The first file has an active tip, facilitating its penetration into the filling material, while D2 and D3 are with passive tips to avoid procedural errors, such as perforations, ledging or stripping, during their use (24).

Four instruments are found in the R Endo system - Re (\# 25.12) for cleaning the orifice area (1-3mm), R1 (\# 25.08), R2 (\# 25.06), R3 (\# 25.04) used for each canal third, respectively. They all have noncutting tips, three cutting edges and a triangular cross-section. A finishing file Rs (\# 30.04) is also available, if needed (18).

A number of articles compare the effectiveness of the retreatment NiTi systems for removing the root canal filling materials. Discrepancy about the superiority of the aforementioned instruments is presented in the literature. Marques da Silva B et al. compared in their study the effectiveness of ProTaper Retreatment, D-Race and Mtwo Retreatment Systems in the removal of root canal filling material and concluded that PTR left significantly less residual material than D-Race. Raj PKT et al. came to the same findings in their investigation $(26,27)$. Meanwhile, other authors found D-Race to be better and also faster than PTR files in the filling material removal $(28,25)$. However, there are studies that found no statistically significant difference between the systems used $(29,30,31)$. This conflicting data could be addressed to the difference in the sample selection, primary shaping techniques, preparation of the apical area, filling materials and techniques used, etc.

A sophisticated number of articles examine ProTaper Retreatment system's ability to remove filling materials, confronting it with other retreatment system. The articles investigating the other retreatment systems are few.

The difficulties in the contemporary endodontic retreatment make some authors use for the removal of filling materials $\mathrm{NiTi}$ instruments which are originally designed for initial canal shaping. Files with different motions have been examined - with continuous rotation (ProTaper Next, Dentsply, Ballaigues, Switzerland) (32,33), reciprocation (Reciproc and Reciproc Blue, VDW, Munich, Germany), Wave One and Wave One Gold, Dentsply, Ballaigues, Switzerland) $(11,13,14,34-37)$ or adaptive motion (TF Adaptive, Kerr, Orange, CA, USA) $(10,12)$.

Based on the experimental results, the researchers concluded that the reciprocating systems are equally effective in removing the root canal filling materials compared to the rotary retreatment systems in general $(16,38,39)$. Nevertheless, the first one are more rapid and remove fillings faster, due to their specific motion, file design (more cutting edges) and the simplicity of the single - file systems $(15,40,41)$. Other investigators, like Jorgensen B et al., came to opposite conclusions. In their study they compared the efficacy of ProTaper Universal Retreatment and WaveOne systems in removing the root canal filling material from mandibular molars obturated with two different techniques. They stated that ProTaper Retreatment system was faster and more efficient in removing the filling material than WaveOne, regardless of the filling technique used in the samples (42).

$\mathrm{Gu}$ et al. reported that the use of files with continuous rotation results in less extruded filling material apically and cleaner apical third of the root canal, due to their ability to take out debris towards the orifice (43). Another current study (44) stated that the use of reciprocating files with small tip sizes resulted in a small amount of apical extrusions because of the compacted gutta-percha in the apical area. 
Many investigators observe remnants of the filling material on the root canal walls, especially in the apical third. The complex anatomy of the root apex makes it difficult to be managed and increases the incidence of procedural errors and flare-ups $(21,45,46,47)$. An additional shaping and further enlargement with one or even two sizes bigger files (40) have been proposed for better cleaning of the apical area $(12,13,26)$. Additional instrumentation weakens the root structure and can cause perforations, zipping, transportation, especially in curved canals. G.Navares et al. reported that PTN and Reciproc could be safely used for removing the gutta-percha and sealer in curved canals as they rotate in the center of the apical third, preserving its original anatomy (33).

\section{Conclusion}

No single technique described in the up-to-date literature is considered $100 \%$ effective in removing root filling materials. Although $\mathrm{NiTi}$ instruments, specifically designed for retreatment have been developed, they have some limitations. Supplementary approaches have to be introduced for more efficient cleaning of the root canal walls and for better prognosis of the endodontic retreatment cases in the daily dental practice.

\section{References}

1. Ng Y-L, Mann V, Gulabivala K. Tooth survival following non-surgical root canal treatment: a systematic review of the literature. Int Endod J. 2010 Mar;43(3):171-189.

2. Silva EJNL, Belladonna FG, Zuolo AS, Rodrigues E, Ehrhardt IC, Souza EM et al. Effectiveness of XPendo Finisher and $\mathrm{XP}$-endo Finisher $\mathrm{R}$ in removing root filling remnants: a micro-CT study. Int Endod J. 2018 Jan;51(1):86-91.

3. Rao LN, Hedge P, Hedge MN. Rotary in Retreatment:a Review. IJSR. 2016 June; 5(6):16-18.

4. Virdee S S, Thomas M B M. A practitioner's guide to gutta-percha removal during endodontic retreatment. Br Dent J. 2017 Feb 24;222(4):251-257.

5. Cordeiro KF, Silva DF, Filho IDJ, Castro FPL. Current Protocols for Endodontic Retreatment: A Review. J Odontol. 2018, 2:3.

6. Duncan HF, Chong BS. Removal of filling materials. Endodontic Topics. 2011 May; 19(1):33-57.

7. Rossi-Fedele G, Ahmed HM. Assessment of Root Canal Filling Removal Effectiveness Using Microcomputed Tomography: A Systematic Review. J Endod. 2017 Apr;43(4):520-526.

8. Karova E. Nickel-titanium Rotary instruments - a guide for students. Sofia, Valdex LTD, 2015.

9. Zupanc J, Vahdat-Pajouh N, Schäfer E. New thermomechanically treated NiTi alloys - a review. Int Endod J. 2018 Oct;51(10):1088-1103.

10. Akbulut MB, Akman M, Terlemez A, Magat G, Sener S, Shetty H. Efficacy of Twisted File Adaptive, Reciproc and ProTaper Universal Retreatment instruments for root-canal-filling removal: A cone-beam computed tomography study. Dent Mater J. 2016;35(1):126-131.

11. Azim AA, Wang HH, Tarrosh M, Azim KA, Piasecki L. Comparison between Single-file Rotary Systems: Part 1 - Efficiency, Effectiveness, and Adverse Effects in Endodontic Retreatment. J Endod. 2018; 44:17201724.

12. Crozeta BM, Silva-Sousa YT, Leoni GB, Mazzi-Chaves JF, Fantinato T, Baratto-Filho F, et al. MicroComputed Tomography Study of Filling Material Removal from Oval-shaped Canals by Using Rotary, Reciprocating, and Adaptive Motion Systems. J Endod. 2016 May;42(5):793-797.

13. De-Deus G, Belladonna FG, Zuolo AS, et al. 3-dimensional ability assessment in removing root filling material from pair-matched oval-shaped canals using thermal-treated instruments. J Endod. 2019; 45(9):1135-1141. 
14. De-Deus G, Belladonna FG, Zuolo AS, Simões-Carvalho M, Santos CB, Oliveira DS et al. Effectiveness of Reciproc Blue in removing canal filling material and regaining apical patency. Int Endod J. 2019 Feb;52(2):250-257.

15. Delai D, Jardine AP, Mestieri LB, Boijink D, Fontanella VRC, Grecca FS et al. Efficacy of a thermally treated single file compared with rotary systems in endodontic retreatment of curved canals: a micro-CT study. Clin Oral Investig. 2019 Apr;23(4):1837-1844.

16. Madarati AA, Al-Nazzawi AA, Sammani AMN, Alkayyal MA. The efficacy of retreatment and new reciprocating in removing a guuta-percha-based filling material. J Taibah Uni Med Sci. 2018 June; 13(5):452-458.

17. Rodrigues CT, Duarte MAH, Milanezi de Almeida M, Bombarda de Andrade F, Bernardineli N. Efficacy of CM-Wire, M-Wire, and Nickel-Titanium Instruments for Removing Filling Material from Curved Root Canals: A Micro-Computed Tomography Study.. J Endod. 2016 Nov;42(11):1651-1655.

18. Fenoul G, Meless GD, Pérez F. The efficacy of R-Endo rotary NiTi and stainless-steel hand instruments to remove gutta-percha and Resilon. Int Endod J. 2010 Feb;43(2):135-141.

19. Kfir A, Tsesis I, Yakirevich E, Matalon S, Abramovitz I. The efficacy of five techniques for removing root filling material: microscopic versus radiographic evaluation. Int Endod J. 2012 Jan;45(1):35-41.

20. Madani ZS, Simdar N, Moudi E, Bijani A CBCT Evaluation of the Root Canal Filling Removal Using DRaCe, ProTaper Retreatment Kit and Hand Files in curved canals. Iran Endod J. Winter 2015;10(1):69-74.

21. Mollo A, Botti G, Goldoni NP, Randellini E, Paragliola R, Chazine M et al. Efficacy of two Ni-Ti systems and hand files for removing gutta-percha from root canals. Int Endod J. 2012 Jan;45(1):1-6.

22. Patil A, Mali S, Hegde D, Jaiswal H, Saoji H, Edake DN. Efficacy of Rotary and Hand Instrument in removing Gutta-percha and Sealer from Root Canals of Endodontically Treated Teeth. J Contemp Dent Pract. 2018 Aug 1;19(8):964-968.

23. Garg A, Nagpal A, Shetty S , Kumar S , KK , Garg A. Comparison of Time Required by D-RaCe, REndo and Mtwo Instruments for Retreatment: An in vitro Study. J Clin Diagn Res. 2015 Feb;9(2):ZC47-49.

24. Marfisi K, Mercade M, Plotino G, Duran-Sindreu F, Bueno R, Roig M. Efficacy of three different rotary files to remove gutta-percha and Resilon from root canals. Int Endod J. 2010 Nov;43(11):1022-1028.

25. Rödig T, Hausdörfer T, Konietschke F, Dullin C, Hahn W, Hülsmann M. Efficacy of D-RaCe and ProTaper Universal Retreatment NiTi instruments and hand files in removing gutta-percha from curved root canals - a micro-computed tomography study. Int Endod J. 2012 Jun;45(6):580-589.

26. Marques da Silva B, Baratto-Filho F, Leonardi DP, Henrique Borges A, Volpato L, Branco Barletta F. Effectiveness of ProTaper, D-RaCe, and Mtwo retreatment files with and without supplementary instruments in the removal of root canal filling material. Int Endod J. 2012 Oct;45(10):927-932.

27. Raj PKT, Mudrakola DP, Baby D, Govindankutty RK, Davis D, Sasikumar TP et al. Evaluation of Effectiveness of Two Different Endodontic Retreatment Systems in Removal of Gutta-percha: An in vitro Study.. J Contemp Dent Pract. 2018 Jun 1;19(6):726-731.

28. Colaco AS, Pai VA. Comparative Evaluation of the Efficiency of Manual and Rotary Gutta-percha Removal Techniques.J Endod. 2015 Nov;41(11):1871-1874.

29. Akhavan H, Azdadi YK, Azimi S, Dadresanfar B, Ahmadi A. Comparing the Efficacy of Mtwo and DRaCe Retreatment Systems in Removing Residual Gutta-Percha and Sealer in the Root Canal. Iran Endod J. Summer 2012;7(3):122-126.

30. Dadresanfar B, Iranmanesh M, Mohebbi P, Mehrvarzfar P, Vatanpour M. Efficacy of Two Rotary NiTi Instruments in Removal of Resilon/Epiphany Obturants. Iran Endod J. Fall 2012;7(4):183-188.

31. Nasiri K, Wrbas K-T. Comparison of the efficacy of different Ni-Ti instruments in the removal of guttapercha and sealer in root canal retreatment. Indian J Dent Res. Jul-Aug 2020;31(4):579-584.

32. Martins MP, Duarte MAH, BC, Kato AS, Bueno CES. Effectiveness of the ProTaper Next and Reciproc Systems in Removing Root Canal Filling Material with Sonic or Ultrasonic Irrigation: A Micro-computed Tomographic Study. J Endod. 2017 Mar;43(3):467-471. 
33. Nevares G, de Albuquerque DS, Freire LG, Romeiro K, Fogel HM, Dos Santos M, et al. Efficacy of ProTaper NEXT compared with Reciproc in removing obturation material from severely curved root canals: A Micro-Computed Tomography Study. J Endod. 2016; 42(5):803-808.

34. Kaloustian MK, Nehme W, Hachem CEl, Zogheib C, Ghosn N, Mallet JP et al. Evaluation of two shaping systems and two sonic irrigation devices in removing root canal filling material from distal roots of mandibular molars assessed by micro CT. Int Endod J. 2019 Nov;52(11):1635-1644.

35. De-Deus G, Belladonna FG, Silva EJNL et al. Micro-CT Evaluation of Non-instrumented Canal Areas with Different Enlargements Performed by NiTi Systems. Braz Dent J. Nov-Dec 2015;26(6):624-629.

36. De Rosa et al. Micro-CT evaluation of root filling removal after three stages of retreatment procedure. Braz Dent J. 2015; 26(6):612-618.

37. Rios Mde A, et al. Efficacy of 2 reciprocating systems compared with a rotary retreatment system for gutta-percha removal. J Endod. 2014 Apr;40(4):543-546.

38. Colombo APM, Fontana CE, Godoy A, De Martin AS, Kato AS, Rocha DG-P et al. Efectiveness of the waveone and ProTaper $D$ systems for removing gutta-percha with or without a solvent. Acta Odontol. Latinoam.2016; 29(3):262-267.

39. Faus-Matoses V, Pasarín-Linares C, Faus-Matoses I, Foschi F, Sauro S, Faus-Llácer VJ. Comparison of Obturation Removal Efficiency from Straight Root Canals with ProTaper Gold or Reciproc Blue: A MicroComputed Tomography Study. J Clin Med. 2020 Apr 18;9(4):1164.

40. Silva EJ, Orlowsky NB, Herrera DR, Machado R, Krebs RL, Coutinho-Filho Tde S. Effectiveness of rotatory and reciprocating movements in root canal filling material removal. Braz Oral Res. 2015;29:1-6.

41. Zuolo AS, Mello JE Jr, Cunha RS, Zuolo ML, Bueno CE.Efficacy of reciprocating and rotary techniques for removing filling material during root canal retreatment. Int Endod J. 2013 Oct; 46(10):947-953.

42. Jorgensen B, Williamson A, Chu R, Qian F. The Efficacy of the WaveOne Reciprocating File System versus the ProTaper Retreatment System in Endodontic Retreatment of Two Different Obturating Techniques. J Endod. 2017 Jun;43(6):1011-1013.

43. Gu LS, Ling JQ, Wei X, Huang XY.Efficacy of PTU-R system for gutta-percha removal from root canals. Int Endod J. 2008 Apr; 41:288-295.

44. Monguilhott Crozeta B, Damião de Sousa-Neto M, Bianchi Leoni G, Francisco Mazzi-Chaves J, Terezinha Corrêa Silva-Sousa Y, Baratto-Filho F. A micro-computed tomography assessment of the efficacy of rotary and reciprocating techniques for filling material removal in root canal retreatment. Clin Oral Investig. 2016 Nov;20(8):2235-2240.

45. Arruda ES, Sponchiado-Júnior EK, Pandolfo MT, Fredson MAC, Lucas Garcia LFR, Marques AAF. Apical Transportation and Centering Ability After Root Canal Filling Removal Using Reciprocating and Continuous Rotary Systems: A CBCT Study. Eur J Dent. 2019 Oct;13(4):613-618.

46. Topçuoğlu HS, Demirbuga S, Topçuoğlu G. Evaluation of apically extruded debris during the removal of canal filling material using three different $\mathrm{Ni}-\mathrm{Ti}$ systems and hand files in teeth with simulated apical root resorption. Int Endod J. 2020 Mar;53(3):403-409.

47. Versiani M, Basrani B, Sousa-Neto MD. The Root Canal Anatomy in Permanent Dentition. Springer International Publishing, 2018 May.

\section{Corresponding author:}

Dr. Sherihan Zongova-Adem,

Center of Integrated Dental Medicine, Faculty of Dental Medicine, Medical University, Sofia;

01, St. Georgi Sofiiski blvd., 1431 Sofia, Bulgaria.

Tel: +359 895782414,

E-mail: dr.zongova@gmail.com 